\title{
Geological Analysis of Nianfa Coal Mine Project at Shatan, Huairen city, Guizhou Province
}

\author{
Fuyan Pan \\ College of Resources and Environmental Engineering, Guizhou Institute of Technology, Guiyang, \\ 550003, China \\ fuyanpan2013@163.com
}

Keywords:characteristics of rock formation, minableseam, Nianfa coal mine.

\begin{abstract}
Nianfa coal mine project at Shatan, Huairen city, Guizhou province, which mainly includes petrofabric features and geological features of minable roof and baseboard, and the research result shows: 1,the project geological petrofabric of research area has three types: hard, flabby and loose petrofabric; 2 , the structure of loose petrofabric is loose, the mechanical strength is high, and the stability of some area is bad; 3 , the compressive strength of minable and baseboard are low, the stability is weak, so we shall prevent many problems while mining.
\end{abstract}

\section{Introduction}

Coal is an important resource, and the power system of China relies much on coal[1-2]. Coal mining is a high risk work[3-4], so the project geological analysis of coal mine is a necessary work. Guizhou province is rich in coal mine, so this paper has analyzed geological conditions of Nianfa coal mine project at Shatan, Huairen city, Guizhou province, and gives guidance to coal mining.

\section{Geological background}

Nianfa coal mine locates at Shatan town, Huairen city, Guizhou province, and belongs to Shatan town, Huairen city. The mine and surrounding area stays at west side of Erlang syncline Yangzi (Pt) paraplatform (Z-T2), north Guizhouplatformuprise, north Zunyi (D-C) broken archtectonic deformation region (the detail is showed in the region geological map). It mainly includes carbonatiteand clastic rocksdeposition, and the direction of strata is north east, the tendency is south east, the dip angle is 14 to $20^{\circ}$. The exposure strata of this area, from ancient to new, are: Cambrian system, Ordovician, silurian system, Dyas, triassic system, Jurassic system, quaternary system, which are sporadically distributed at the strata of different eras (Fig.1). Coal measures are longtan formation, which are siltstone clay rock with carbonatite and coal (seam) multilayers.

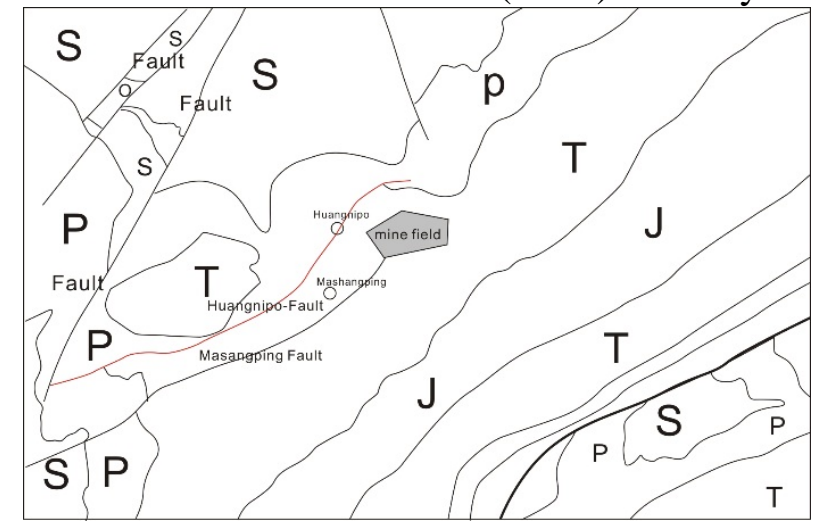

Fig. 1 the geological map in the researched area

In the middle part of syncline, north and west part develops form north and east direction into Masangping fault and Huangnipo fracture, whose features are as follows: erlang syncline dam starts from Guantian dam at the south and west direction to erlang dam at the north side, which shows the trend from north and east direction to south and west side for about $28 \mathrm{~km}$. The strata of both wings 
are symmetry, the core strata is Jurassic system Shaximiao team $\left(\mathrm{J}_{2} \mathrm{~s}\right)$, the exposure field at two sides is Jurassic system artesian well group $\left(\mathrm{J}_{1-2} \mathrm{zl}\right)$, triassicsystemXujiahe team $\left(\mathrm{T}_{3} \mathrm{xj}\right)$, Songzikan team $\left(\mathrm{T}_{2} \mathrm{~s}\right)$, Maocaopu team $\left(\mathrm{T}_{1} \mathrm{~m}\right)$, Yelang formation $\left(\mathrm{T}_{1} \mathrm{y}\right)$, DyasShangtongChangxing team $\left(\mathrm{P}_{3} \mathrm{C}\right)$, Longtan formation $\left(\mathrm{P}_{3} \mathrm{l}\right)$,ZhongtongMaokou formation $\left(\mathrm{P}_{2} \mathrm{~m}\right)$, Xixia team $\left(\mathrm{P}_{2} \mathrm{q}\right)$, silurian system $\left(\mathrm{S}_{1}\right)$. The coal seam is in the strata of DouShangtong and Longtan formation.

\section{Petrofabric division of project geology}

According to the material component and its combination relation of different petrofabric, physico-mechanical index and other project geological features, the project geological petrofabric in the mining area can be divided into three types: hard, flabby and loose petrofabric. According to the RQD\% value (table 1) of rock core and the mainphysico-mechanical index (table 2) statistics, we can judge the rock quality of different petrofabric and the integrity of rock mass.

Table 1. Statistical table of drilled rock core quality (RQD\%)

\begin{tabular}{|c|c|c|c|c|c|c|c|}
\hline $\begin{array}{c}\text { Number of } \\
\text { hole }\end{array}$ & T1m & T1y3 & T1y2 & T1y1 & P3c & P3l & P2m \\
\hline ZK101 & & 85 & 83 & 82 & 70 & 38 & 88 \\
\hline ZK102 & 86 & 83 & 90 & 79 & 85 & 64 & 89 \\
\hline ZK201 & 88 & 78 & 91 & 82 & 91 & 46 & 85 \\
\hline ZK301 & & & & & & 60 & 89 \\
\hline ZK302 & 76 & 88 & 58 & 76 & 50 & 90 \\
\hline
\end{tabular}

Table2. Statistical table of main physico-mechanical indexof rock

\begin{tabular}{|c|c|c|c|c|c|}
\hline \multirow{2}{*}{$\begin{array}{l}\text { Number } \\
\text { of sample }\end{array}$} & \multirow{2}{*}{ Feature of rock } & \multirow{2}{*}{$\begin{array}{l}\text { Strength of } \\
\text { extension } \\
\mathrm{MPa}\end{array}$} & \multirow{2}{*}{$\begin{array}{c}\text { Compressive test of } \\
\text { saturation single axle } \\
\text { Ultimate strength } \\
(\mathrm{MPa})\end{array}$} & \multicolumn{2}{|c|}{ Strength test of shearing } \\
\hline & & & & $\mathrm{c}^{\prime}(\mathrm{MPa})$ & $\varphi^{\prime}\left({ }^{\circ}\right)$ \\
\hline M1 & $\begin{array}{l}\text { Packsand to } \\
\text { medium } \\
\text { sandstone }\end{array}$ & 4.03 & 82.9 & 4.71 & 38.4 \\
\hline M2 & Packsand & 0.26 & 5.7 & 0.43 & 32.1 \\
\hline M3 & $\begin{array}{l}\text { medium } \\
\text { sandstone }\end{array}$ & 0.65 & 14.2 & 0.89 & 33.8 \\
\hline M4 & Packsand & 1.83 & 32.7 & 1.95 & 35.2 \\
\hline M5 & $\begin{array}{l}\text { medium } \\
\text { sandstone }\end{array}$ & 0.22 & 4.5 & 0.38 & 31.6 \\
\hline M6 & Packsand & 2.19 & 37.0 & 2.12 & 35.8 \\
\hline M7 & Packsand & 3.62 & 69.7 & 4.36 & 37.5 \\
\hline M8 & Packsand & 1.06 & 21.4 & 1.41 & 34.7 \\
\hline M9 & siltstone & 4.38 & 92.5 & 4.97 & 39.2 \\
\hline M10 & siltstone & 0.29 & 7.1 & 0.49 & 32.8 \\
\hline M11 & Packsand & 0.81 & 17.2 & 1.23 & 34.1 \\
\hline M12 & $\begin{array}{l}\text { argillaceous } \\
\text { siltstone }\end{array}$ & $\underline{-}$ & 0.6 & 0.15 & 26.3 \\
\hline M13 & Packsand & 5.21 & 111.8 & 5.08 & 41.6 \\
\hline M14 & Carbon siltstone & (n) & 1.4 & 0.23 & 27.9 \\
\hline
\end{tabular}

\section{Hardpetrofabric}

It mainly includes $\mathrm{T}_{1} \mathrm{~m}, \mathrm{~T}_{1} \mathrm{y}_{2}, \mathrm{P}_{3} \mathrm{c}, \mathrm{P}_{2} \mathrm{~m}$. They are mainly thin to medium and thick stratiform limestone, dolomite and chert limestone. The fresh rock of this type of rock core is hard, brittle, the strength is even, and the compressive strength is usually more than 60MPa. The RQD value of 
T1mrock core is 95\%, the quality of rock is nice and the rock mass of complete; The RQD value of T1y2 rock core is $65-95 \%$, the quality of rock is bad-good, and the rock mass is relatively complete to complete; The RQD value of P3c rock core is 70-96\%, the quality of rock is bad-good, the rock mass is broken to complete; The RQD value of P2mrock core is 65-96\%, the quality of rock is bad-good, the rock mass is broken to complete.

\section{Semi-hard with weak petrofabric}

It includes $\mathrm{T}_{1} \mathrm{y}^{3}, \mathrm{~T}_{1} \mathrm{y}^{1}, \mathrm{P}_{3}$, which are mainly clastic rocks, and the features of rock are: mudstone, silty mudstone, siltstone, packsand, argillaceous siltstone, part of limestone, marlstone, argillaceous limestone, multilayer coal and seam. The strength of this petrofabric is low, which is easy to get weathering in the air, the compressive strengths are mainly low, and part of them get soft easy with water. The compressive strength of saturation single axle of the rock $0.6-111.8 \mathrm{MPa}$, the strength of extension is $0.22-5.21 \mathrm{Mpa}$, the shear strength is $0.15-5.08 \mathrm{Mpa}$, and the shear angle is $26.3-41.6^{\circ}$. the RQD value of $\mathrm{T}_{1} \mathrm{y}^{3}$ rock core is $39 \%$, the rock quality is bad, and the rock mass is brittle; the RQD value of $\mathrm{T}_{1} \mathrm{y}^{1}$ rock core is $58-82 \%$ the quality of rock is bad-good, and the rock mass is relatively brittle to complete; the RQD value of $\mathrm{P}_{3}$ lrock core is43-84\%, the quality of rock is bad-good, and the rock mass is relatively brittle to complete.

\section{Loose petrofabric}

It mainly includes four series, the rock feature is clay and mild clay, and partly dimension stone with limestone. It mainly distributes at seasonal gully, mountain depression, slack land and each slope. The structure of this petrofabric is loose, superficial part shows pluripotent state after soaking, the mechanical strength is low, and it has certain but weak water permeability. After comprehensive analysis, we consider that, the structure of this petrofabric is loose, its mechanical strength is low, and it always distributes at superficial slope and low-ling area. The stability of some area with harmful terrain is relatively bad.

\section{The project geological feature and stability of minable coal roof and baseboard rock}

Minable seam of the mining area has three layers:C4,C9,C13,C15, according to the rock feature combination of coal roof and baseboard and physical mechanics, we has separately assessed the stabilities of its roof and baseboard: 1 , according to the statistics of test data, the saturation single axle or natural compressive strength of packsand, siltstone, argillaceous siltstone, carbonaceous mudstone and clay rock is $0.6-111.8 \mathrm{Mpa}$, and its stability is bad to relatively good; 2, C4: the direct roof is packsand, so the compressive strength is high, the stability is good; the baseboard is argillaceous siltstone, so the compressive strength is low, the stability is bad; 3, C9: the direct roof and baseboard are argillaceous siltstone, so the compressive strength is low, the stability is bad; 4, C13, the direct roof is packsand, the direct baseboard is clay rock, so the compressive strength is low, the stability is bad; in a word, the compressive strength of the roof and baseboard of each seam is low, the stability is bad, so we shall prevent roof fall, wall caving, heaving floor and other problems while mining.

\section{Conclusion}

Through the comprehensive analysis petrofabric feature and geological features of minable roof and baseboard at Nianfa coal mine project at Shatan, Huairen city, Guizhou province, we have got following conclusions: 1,the project geological petrofabric of research area has three types: hard, flabby and loose petrofabric; 2 , the structure of loose petrofabric is loose, the mechanical strength is high, and the stability of some area is bad; 3 , the compressive strength of minable and baseboard are low, the stability is weak, so we shall prevent roof fall, wall caving, heaving floor and other problems while mining. 


\section{Reference}

[1]. Hong Zhang, Xianglan Jin, Guihong Li, et al. Comparison of coalfields and coal-mining geological conditions of the main coal-producing countries in the world. Coal geology and exploration. Vol. 35 (2007) No.6, p. 1-9.

[2]. Keliang Wang, Baochen Yang, Li Yang. Fuzzy IdentificationModel of Safety Evaluation on M ining Condition in Coal Mine. Coal Science and Techno logy. Vol. 37 (2009) No.7, p. 73-76.

[3]. Hong Zhang, Yujin Xia, Qun Zhang. Coal-mining geological conditions and explorations of deep coal deposits: status and problems. Coal geology and exploration.Vol. 37 (2009) No.1, p. 1-12. [4]. Junjie Chen, Hongyou Liang. Research the Destruction to Land Resources by Mining Coal and Countermeasure. Coal technology. Vol. 25 (2006) No.6, p. 1-3. 